on "objective standards" per se and a correspondingly greater premium on careful selection of able and impartial test administrators will provide a more effective application of a common measure to all candidates. When judicial review of a personality rating is sought, a greater presumption of validity should be accorded the Commission's findings; and the competency of the examiner, not the "objectivity" of his appraisals, should govern the outcome. The court's role should be limited to adjudicating charges of caprice or fraud, not re-appraising personality.

\title{
PROPOSALS FOR INTERLOCUTORY APPEALS
}

Is the federal courts, appeals from interlocutory orders have been prohibited, with certain statutory exceptions, ${ }^{1}$ since the initial formulation of the "final judgment rule"' in the Judiciary Act of $1789 .^{3}$ Justification of this rule is generally couched in terms of expeditious litigation. ${ }^{4}$ Presumably, the great majority of interlocutory decisions are correct, and many erroneous rulings prove harmless when viewed in light of the final disposition of the case. system permitting the interruption of trial progress to allow a fragmentary

1. Appellate courts have jurisdiction to entertain appeals from interlocutory orders (1) granting, continuing, modifying, refusing or dissolving injunctions, or refusing to dissolve or modify injunctions; (2) appointing receivers, or refusing to wind up receiverships; (3) determining the rights and liabilities of the parties to admiralty cases in which appeals from final decrees are allowed; (4) in civil actions for patent infringement which are complete except for accounting. 28 U.S.C. $\$ 1292$ (1948).

2. Twenty consecutive definitions of a final judgment are listed in 4 C.J.S. 187. For a thorough analysis of the rule, see Crick, The Final Judgment as a Basis for Appeal, 41 Yale L. J. 539 (1932).

3. The Federal Judiciary Act of 1789, 1 STAT. 73 (1789), provided for appeals from "final judgments or decrees" only. This limitation applied to appeals from the highest state courts to the Supreme Court $(\$ 25)$; from district courts to circuit courts ( $\$ 22)$; and, by implication, from the circuit courts to the Supreme Court $(\$ 13)$. When the circuit courts of appeals were established in 1891, their appellate jurisdiction was similarly dependent on the finality of the district (or circuit) court's decision. 26 STAT. 828 (1891). The latest revision of the Judicial Code provides: "The courts of appeals shall have juriscliction of appeals from all final decisions of the district courts. . . "28 U.S.C. $\S 1291$ (1948).

4. "To be effective, judicial administration must not be leaden-footed. Its momentum would be arrested' by permitting separate reviews of the component elements in a unified cause." Mr. Justice Frankfurter, in Cobbledick v. United States, 309 U.S. 323, 325 (1940).

5. “... [M] any mistakes, apparently important at the time, will be seen to bo trivial from the perspective of a final disposition of the case, and ... disputes will therefore be more expeditiously settled." Judge Frank, in Perkins v. Endicott Johnson Corp., 128 F.2d 208, 212 (2d cir. 1942), aff'd 317 U.S. 501 (1943). Sec Libby-OwensFord Glass Co. v. Sylvania Indust. Corp., 154 F.2d 814, 815 (2d Cir. 1946), cert. denied, 328 U.S. 859 (1946). 
review of each order would occasion vexatious delays, ${ }^{\circ}$ heavy costs, ${ }^{7}$ and overburdened appellate calendars. 8

In many instances, however, the final judgment rule may be a wasteful formality; and under certain circumstances it can gravely jeopardize the rights of litigants. ${ }^{9}$ If, for example, in a receivership proceeding or an action for partition, erroneous decrees are made directing the sale or transfer of property, an appeal months or years later from a final decision may be of little avail. ${ }^{10}$ It will be impossible to retrieve the land in question. Moreover, weels

6. "Reasons other than conservation of judicial energy sustain the limitation [of the final judgment requirement]. One is elimination of delays caused by interlocutory appeals." Mrr. Justice Rutledge, in Catlin v. United States, 324 U.S. 229, 234 (1945).

7. The relation of delay to expense is well illustrated in the case of American MFschine and Mietals, Inc v. De Bothezat Impeller Co., 173 F.2d 890 (2d Cir. 1949). In this action the plaintiff was seeking a judgment declaratory of his right to terminate a patent contract. The defendant, through a series of procedural maneuvers, had avoided trial for over two years. During this period the plaintiff was obliged to pay over $\$ 70,000$ royalties under the contract it sought to terminate. Brief for Plaintifi-Aprellec, p. 4. As the case was nearing trial, the district judge made a preliminary order striking four defenses for insufficiency, severing the remaining issues, directing a separate trial of the basic issues, and granting a preference of that separate trial. The defendant then attempted to appeal from this order, but his petition was dismissed by the court of appeals in a per curiam opinion which held the order to be interlocutory.

8. See Morgantown v. Royal Ins. Co., 169 F.2d 713, 715 (4th Cir. 1948) ("Trials ought not to be delayed and appellate dockets crowded by appeals from interlocutory orders. ...").

9. The malfunctioning of the final judgment rule in these two resprets has led to the incisive criticism of Crick, supra note 2. And see Note, 47 Cor. L. Rev. 239 (1947).

Where hardship is occasioned by an erroneous interlocutory ruling, the concept of finality is sometimes ballooned to permit an appeal; in other instances, interlocutory orders are made appealable by a judicial extension of the statutory exceptions to the final judgment rule. See note 1 supro. Ettleson v. Metropolitan Life Ins. Co., 317 U.S. 188 (1942), is an example of the latter technique. In this case an order directing that an equitable counterclaim be heard and disposed of by the court sitting in equity prior to a trial of the action at law was held to be, in effect, an interlocutory injusnction and hence appealable. Professor J. W. Moore has sharply criticized this holding as ". . . a procedural anachronism which is at odds with the new federal procedure, and which flies in the face of the well-settled federal policy against interlocutory appeals; ... it is only by an ingenious resort to the obsolete that the Court can bring the Etfleson case within the statutory authorization of an interlocutory appeal." 3 Afoose, Frraral PRACт1се 29 (Supp. 1942). Judge Clark in Ring v. Spina, 166 F.2d 546, 548 (2d Cir. 1948), acknowledged the force of this criticism, but went on to say: ". . . for our purposes we must of course consider it [the Ettlesons case] as gloss upon the statute, intended to promote prompt settlement in a case of the important question of form of trial."

10. A decree directing land to be sold in an action for partition is interlocutory. Sowell v. Sowell, 101 Miss. 623, 57 So. 626 (1912). And see opinion of Chief Justice Taney in Forgay v. Conrad, 6 How. 201, 205 (U.S. 1848), in which he varns the circuit courts of the danger of cancelling deeds and ordering property sold and delivered prior to a final judgment. Cf. Mfilwaukee \& St. Paul RR Co. v. Soutter, 131 U.S. Append. kxwri (1868) (decrees directing payment of rent by one railroad to receiver of second railroad not final).

The injustice occasioned by the final judgment rule most often arises in cases of an 
of actual litigation $<$ may have been wasted when a pre-trial ruling is held reversible error. ${ }^{11}$ At present, even though the trial judge is uncertain as to the correctness of his ruling, there is no way of obtaining a prompt determination of its propriety.

To a limited extent appellate courts have exercised supervisory power over interlocutory rulings by means of prerogative writs. In theory these extraordinary remedies lie only from final judgments. ${ }^{12}$ An exception is made, however, where a lower court improperly assumes or denies jurisdiction. ${ }^{13}$ Thus, where interlocutory orders grant or refuse changes of vente, ${ }^{14}$ decline to substitute parties to suits, ${ }^{15}$ or remove cases from the jury docket, ${ }^{10}$ appellate courts have found error "jurisdictional." In these instances writs of mandamus or prohibition have been granted directing the trial judge to alter his ruling. The common law writ of certiorari has similarly been used. ${ }^{17}$ But in practice the usefulness of these prerogative writs is seriously curtailed by the difficulty of choosing the proper remedy in a given situation. ${ }^{18}$ Technical distinctions between the writs have created lines which are often too fine for perception. And the concept of "jurisdiction" is so nebulous that litigants are

equitable nature, where litigation is long and complicated. In England equity practice never recognized the common law rule that only final judgments were appealable. This may be explained historically by the manner in which the courts of chancery developed. Originally, suits in equity began and ended in the same court. The Chancellor was regarded as the sole judge in chancery, and he reviewed all the interlocutory orders and decrees of the masters, who were regarded as mere clerks. It proved more convenient, under such circumstances, to review intermediate decisions as the case progressed than to await a final judgment. See Crick, supra note 2 , at 547.

11. For example, the current trial in New York of the eleven leaders of the Communist Party has been in progress for several months. During pre-trial proceedings the defendants objected to the method used in selecting the jury, but their objection was overruled by Judge Medina. If the final judgment is adverse to the defendants, this issue will undoubtedly be raised on appeal; and should the preliminary ruling be held erroneous, months of trial litigation will have been wasted.

12. Ferris, Extraordinary Legal Remedies $\$ 299$ (1926). See Bank of Columbia v. Sweeny, 1 Pet. 567, 569 (U.S. 1828); Roche v. Evaporated Milk Ass'n, 319 U.S. 21, 30 (1943).

13. Ex parte United States, 319 U.S. 730 (1943); Ex parte Skinner \& Eddy Corpa, 265 U.S. 86 (1924).

14. State $e x$ rel. Daily v. Harrison, 215 Ind. 106, 18 N.E.2d 770 (1939) (mandamus available but denied on the merits); State ex rel. Martin v. Super. Ct., 97 Wash. 358, 166 Pac. 630 (1917) (prohibition granted).

15. In re Connaway, 178 U.S. 421 (1900).

16. Ex parte Simmons, 247 U.S. 231 (1918).

17. Carpenter v. Central Vt. Ry., 84 Vt. 538, 80 Atl. 657 (1911) (denial of petition for change of venue reviewable by certiorari). Technically, certiorari-unlike prohibition and mandamus-is a corrective rather than a preventive measure. At common law it issued subsequent to a final judgment in order to bring before the appellate court portions of the record not assigned as error. See Bordwell, Extraordinary Remedics, 9 AMr. LAW \& Proc. 207, 232 (1913).

18. See Crick, supra note 2 , at 563 . 
often unable to determine whether any of these writs is available. 10 Moreover, federal appellate courts have become increasingly reluctant to malie use of these extraordinary remedies to interfere with interlocutory decisions. 28

Prompted by a desire for greater flexibility in the rules governing appeals, Judge Jerome Frank has advocated the adoption of a procedure by which the appellate courts could, at their discretion, grant interlocutory appeals on petition of aggrieved litigants. ${ }^{21}$ The proceedings would be analagous to the issuance of statutory writs of certiorari by the Supreme Court. Recognizing, however, that many interlocutory orders concern purely procedural points, Judge Frank would limit the scope of permissive review to those "decisions of lower courts affecting substantive rights." 2

If discretionary power were vested in appellate courts, erroneous rulings could be corrected without delay. And Judge Frank contends that this procedure would neither lengthen litigation nor crowd appellate calendars. He argues that since considerable time is presently expended by appellate courts in deciding whether an order is "final" or "interlocutory" - _ a meaningless

19. This has led one distinguished scholar to suggest: "The first step toward a rational appellate procedure should be the total abolition of all these forms. ..." Sunderland, The Probleni of Appellate Reriew, 5 TEx. L. KEv. 126, 132 (1923).

20. See Roche v. Evaporated Millk Ass'n, 319 U.S. 21, 26 (1943).

21. See the opinions of Judge Frank in American Mrachine and MLetals, Inc. v. De Bothezat Impeller Co., 173 F.2d $\$ 90$ (2d Cir. 1949) (order directing sepurate trial of basic issues in case and granting preference for that trial held not appealable since interlocutory) (dissenting opinion); United States e.r rol. Sutton y. Mfulcahy, 169 F.2d 94, 102 (2d Cir. 1948) (petition for writ of habeas corpus collaterally attacling jurisdiction of court that committed petitioner for civil contempt held properly denied where jurisdictional issue had been litigated) (dissenting opinion); Clark v. Taylor, 163 F.2d 940, 952 n.12 (2d Cir. 1947) (order holding that a receiver acting for the asserted owner of a chose in action has no title thereto held not appealable since interlocutory) (dissenting opinion); Audi Vision, Inc. v. RCA Mffg. Co., 136 F.2d 621, 626 (2d Cir. 1943) (judgment granting motion for summary judgment dismissing complaint, but not disposing of counterclaim, held not appealable since interlocutory) (concurring opinion); Zallini v. Scheinman, 139 F.2d S95, S9S n.3b (2d Cir. 1943), cort. denicd, 322 U.S. 738 (1944) (order striking claim based on distinct cause of action held final and appelable).

This proposal is roughly synonymous with English procedure. The Judieature Act of 1925 provides: "No appeal shall lie ... without leave of the judge or of the Court of Appeal from any interlocutory order. . ." 15 \& 16 Gro. V. c. 49, \$31(1)(i), 4 HuLs. Stat. 162 (1925). And see the provision in the District of Columbia Code permitting appeals "... from any other interlocutory order, in the discretion of the said United States Court of Appeals for the District of Columbia. . . " D.C. Cove $\$ 17-101$ (1910).

In Mississippi a judge of the Supreme Court may in his diseretion grant an interlocutory appeal "in exceptional cases" in equity. Mirss. Cons Axis. $\$ 1148$ (1942). There is a comparable provision in TeNa. CODE $\$ 903 \$$ (1934).

22. Zalkind v. Scheinman, 139 F.2d S95, S9S n.3b (2d Cir. 1943), ccrt. dcrisd, 322 U.S. 738 (1944).

23. The concept of finality, still "slithery" at the margin, is gradually becoming crystallized by judicial decision. Treatise writers have catalogued hundreds of orders and decrees as appeallable or non-appealable. See 1 OmLrigen, Fenzrac Practice 694 
question in itself-the burden would be little greater if appellate judges could directly determine which orders should be reviewed. ${ }^{24}$

While the proposed remedy unquestionably would correct the deficiency at which it is aimed-the inability of a litigant to obtain a prompt review of trial orders affecting substantive rights-it seemingly fails to counter the objections traditionally levelled at extensive interlocutory appeals. The proposed criterion governing the allowance or denial of petitions for review would, except in those instances where the petition was patently frivolous, necessitate a substantial determination by the appellate court of the merits of each attempted appeal. ${ }^{25}$ Therefore, the courts might be only slightly less burdened than they would be if appeals of interlocutory rulings were permitted as of right. Since the way would be left open for a potential deluge of dilatory petitions for review, this procedure might be transformed into a weapon for the financially strong. Furthermore, in states where interlocutory appeals have been freely permitted, experience has shown that technical procedural points are unduly emphasized, since the appeal is usually from a pre-trial decision. ${ }^{20}$ Stress is placed on form rather than merit, a choice singularly out of line with the spirit of the Federal Rules. ${ }^{27}$

The problem which has evoked Judge Frank's rather drastic proposal might be more satisfactorily solved by vesting in the trial court, rather than the appellate court, discretion to grant interlocutory appeals. ${ }^{28}$ This procedure would

et seq.; Dobie, Federal Jurrsdiction and Procedure $792-7$ (1928); and sce Rector v. United States, 20 F.2d 845, 861-71 (8th Cir. 1927). Nevertheless, the question continues to be extensively litigated. See, e.g., Clark v. Taylor, 163 F.2d 940 (2d Cir. 1947).

24. See Audi Vision, Inc. v. RCA Mfg. Co., 136 F.2d 621, 626 (2d Cir. 1943); Crick, supra note 2 , at 557-8. But Judge Frank suggests that if the additional labors imposed by discretionary appeals prove too great, "... doubtless Congress would provide for the appointment of additional judges." Audi Vision, Inc. v. RCA Mfg. Co., supra, at 627 .

25. See Judge Clark, dissenting in Zalkind v. Scheinman, 139 F.2d 895, 908 (2d Cir. 1943), cert. denied, 322 U.S. 738 (1944).

26. In the New York state courts, appeals may be taken as of right from almost all interlocutory orders. N.Y. PrAC. ACT $\$ 609$ (Clevenger 1947). This has been suggested as the reason for the unusual emphasis on procedural objections in New York state practice. Zalkind v. Scheinman, 139 F.2d 895, 907 n.5 (2d Cir. 1943) (dissenting opinion), cert. denied, 322 U.S. 738 (1944). Moreover, a New York attorney has stated that the frequency of interlocutory appeals in state practice results in a preference by litigants for the federal courts. Harper, Civil Practice in the Federal Couts 81 in Practising Law Institute, Trial Practice (1946).

27. "The objective of the Rules is ... (1) 'Decisions are to be on the merits and not on procedural niceties." 2 Moore, Federal Practice 56 (1948). Scc Moorc v. Illinois Central R.R., 24 F.Supp. 731, 733 (S.D.Miss. 1938).

28. This proposal has previously been advocated in the model rules of the American Judicature Society, XIV Ax. Jun. Soc. Buzl. 181 (1919) ("The trial court may, in its discretion, grant leave to appeal from any other interlocutory order."); see also Moorc \& Vestal, Present and Potential Role of Certification in Federal Appellatc Procedure, 35 V.. L. REv. 1, 7, 45 (1949).

Judge Frank, in a recent opinion, has recognized the desirability of certification. 
be roughly analagous to certification, the district judge possessing power to allow an appeal either at request of counsel or, if decision has been reserved, on his own motion. The trial court, knowing all the facts, is in the best position to determine the advisability of allowing an interlocutory appeal, and it can make a decision without interrupting the progress of the case. ${ }^{20}$ Certification has long been an available technique in many state jurisdictions ${ }^{20}$ and has proven an effective escape from the occasional deleterious consequences of the final judgment requirement. ${ }^{31}$

A practical objection is the possibility that a trial judge may improperly em-

American Machine and Metals, Inc. v. De Bothezat Impeller Co., 173 F.2d 890 (2d Cir. 1949) (dissenting opinion). However, he continues to advocate that overriding discretion be placed in the appellate court, so that the parties might still petition for reviev: should the trial judge refuse to certify.

29. This consideration is outlined in a critique of the proposed rules of appellate procedure in the California state courts published in 15 So. CALIF. L. REv. 500, 504, 512, (1942).

30. AlA. Code, tit. 7, $\$ 745$ (1940); 30 Fld. Stat. Aws. (Sup. Ct. Rule 3\$3) (194\$) ("questions or propositions of law that are determinative of the cause and are without controlling precedent"); IND. LAws c. 76, $\$ 1$ (1937); Misss. Axw. LAws c. 214, $\$ 30$ (1933) ("so affects the merits of the controversy that the matter ought, before further proceedings, to be determined by the full court"); 39 Afrix. Srar. Awr. 605.09(4) (1947) ("order sustaining . . . or overruling a demurrer"); N.D. Laws, c. 32, \$2401, 2402 (1943) ("construction or interpretation is in doubt and vital, or of great moment in the cause") ; N.J. Stat. ANn. \$2:27-202 (1939); N.H. Rev. Laws c. 370, \$15 (1942) ("Questions arising upon exceptions, upon a special verdict, an issue of law, motion for a new trial or in arrest of judgment, or other motion or proceeding"); R.I. GE:. LAws c. 545, $\$ 6$ (1938) ("any question of law . . . of such doubt and importance . . . that it ought to be determined by the supreme court before further proceedings"); VT. Srar. $\$ 2124$ (1947); W. VA. CODE $\$ 578 S$ (1943) ("Any question arising upon the sufficiency of a summons or return of service, or challenge of the sufficiency of a pleading").

Moreover, in the federal courts the recent amendment to Rule 54(b)-authorizing the trial court to determine for purposes of appeal the finality of a limited class of preliminary rulings-implicitly endorses the rationale underlying certification. Rule Fit(b) originally provided: "When more than one claim for relief is presented in an action, the court ... may enter a judgment disposing of such claim." These judgments were held final if the appellate court felt they adjudicated separate "causes of action." The difieulty in defining a "cause of action" led to considerable confusion and much litigation. Sce, e.g., Collins v. Metro-Goldwyn Pictures Corp., 106 F.2d 83 (2d Cir. 1939); Sidis v. F-R Pub. Corp., 113 F.2d $S 06$ (2d Cir. 1940), ccrt. denicd, 311 U.S. 711 (1940). Consequently, in 1947 Rule 54(b) was amended to read: "When more than one claim for relief is presented in an action ... the court may direct the entry of a final judgment upon one or more but less than all of the claims only upon an express determination that there is no just reason for delay and upon an express direction for the entry of judgment." Thus, the appealability of separate judgments is now controlled by the trial judge's determination of finality. See Adnsony Cosmrtrze's Nore ro FEn. R. CN. P., 54(b) (June 1946 Report) ; Notes, 56 Y ALE L. J. 141 (1946), 47 CoL. L. REv. 239, 254 (1947).

31. "Postponement of review of the question here presented, until after a final or appealable decree, would obviously inflict the suspense, inconvenience, and delay from which it was the legislative purpose to relieve" Gulland v. Gulland, 81 W.Va. 4\$7, 488, 94 S.E. 943 (1918). 
ploy his discretionary power. ${ }^{32}$ The effectiveness of certification depends in large measure upon the way in which it is used, abused, or ignored. Where a trial judge is aware of the undue hardship which would arise from an erroneous ruling and is uncertain of applicable law, conscience and prudence should dictate present certification rather than possible future reversal. Since this is the path of least resistance, there is perhaps a danger of too many certified questions. ${ }^{33}$ However, under instructions from the courts of appeals a set of working principles should emerge within each circuit which will guide the trial judge in his decision to certify. ${ }^{34}$

The general requirement of a final judgment should be retained in so far as it realizes its objective of expediting litigation. But where the postponement of appellate review is wasteful or threatens the substantive rights of litigants, some procedure for prompt review should be devised. As a supplement to the final judgment rule, a method of certification, endowing the trial court with discretionary power to allow an immediate appeal, would provide a remedy in the exceptional harsh case without substantially altering the present framework of appellate procedure. ${ }^{35}$

32. See Judge Frank, dissenting in Clark v. Taylor, 163 F.2d 940, 952 n.12 (2d Cir. 1947).

33. The suggestion has, therefore, been made that the certificate of the district caurt be, in effect, a petition that the court of appeals give appellate aid at that point; by this method certification would not invoke the obligatory jurisdiction of the appellate court. Moore \& Vestal, supra note 28 , at 45 . This reserve power is perhaps desirable, in the event that a district judge should attempt to shift to the appellate court all responsibility for making decisions. But generally it may be assumed that any question considered by the trial judge of sufficient doubt and significance to warrant certification will, if unanswered, eventually be returned to the appellate court on an appeal as of right. Moreover, in order to determine whether the trial judge is properly exercising his discretion, it would probably be necessary to explore the merits of cach certified appeal. Therefore, the power to dismiss a certification without answer would be of value only in exceptional circumstances.

34. Considerable local discretion should be allowed in order that each circuit may adjust the flow of interlocutory appeals as the appellate court catches up to or falls behind its obligatory docket. See Moore \& Vestal, supra note 28, at 45.

35. The final judgment rule is a statutory provision; insofar as it would be amended by the extension of the power of certification to the district courts, legislative action would be required. The Enabling Act, 48 Stat. 1064 (1934), 28 U.S.C. $\$ 2072$ (1948), empowering the Supreme Court to construct rules of procedure, does not authorize changes in appellate jurisdiction. See 3 MOORE; Federal Practice 3155 (1938); Clarli, Power of Supreme Court to Make Rules of Appellate Procedure, 49 Hatrv. L. REv, 1303, 1321 (1936).

A Texas statute permitting certification from the district courts to the court of civil appeals was declared invalid on the grounds that it was not a legitimate exercise of either appellate or original jurisdiction within the terms of the state constitution. Morrow v. Corbin, 122 Tex. 553, 62 S.W.2d 641 (1933); see Note, 82 U. of PA. L. Rev. 175 (1933). But this problem would not arise in the federal system, since under the Constitution the jurisdiction of the inferior courts is wholly statutory. U.S. CoNST. Art. III, $\$ 1$; see Kline v. Burke Construction Co., 260 U.S. 226, 234 (1922). 